\title{
PENGARUH PENGETAHUAN KEWIRAUSAHAAN TERHADAP MINAT BERWIRAUSAHA MAHASISWA (STUDI KASUS: MAHASISWA PROGRAM STUDI MANAJEMEN FAKULTAS EKONOMI UNIVERSITAS KATOLIK SANTO THOMAS MEDAN)
}

\author{
Nawary Saragih \\ Fakultas Ekonomi Universitas Katolik Santo Thomas Medan \\ Email: nawary_saragih@yahoo.com
}

\begin{abstract}
:
The purpose of this research is to know how big influence of entrepreneurial knowledge to entrepreneurship interests Student Program the Study of Faculty of Management of Saint Thomas Catholic University Medan. Research type used by descriptive and kuantitatif. Sampel research as much 96 Responder with the method of maximum sampling error intake from population conducted at random (random sampling). Data required to be collected through kuesioner by online. Method Analyse the data used is with the simple linear regression analysis. Result of research descriptively that entrepreneurial knowledge of Student Program the dominant Management Study agree equal to $51,04 \%$ to entrepreneurial knowledge. While equal to 44,17\% that entrepreneurial knowledge can support the Student to hanker the entrepreneurship. Result of examination obtained: 1). Coefficient Determinasi ( $R 2$ ) equal to its 0,230 meaning entrepreneurial knowledge able to explain the entrepreneurship interests of Student equal to 23,0\%, and 77,0 \% is again influenced by other; dissimilar factor which is not explained this research (for example introductory sinergi entrepreneurial knowledge of Business, Makerting, e-commerce). 2). Equation of Regresi $Y=$ $1.966+0,490+e$. Where about mount the signifikan $0.000<0,05$, by $t$-hitung equal to $5.306>t$-tabel equal to 1,65 hence Ho refused its meaning entrepreneurial knowledge own the influence which are positive and signifikan to entrepreneurship interests of Student. Suggested: 1). Because coefficient determinasi ( R2) still equal to its 0,230 meaning still lower the influence of entrepreneurial knowledge able to explain the entrepreneurship interests of Student, hence to support and also to grow the entrepreneurial knowledge of Student needed the make-up of items more aplikatif with the support sinergi from entrepreneurial knowledge other; dissimilar like Business. Marketing, e-commerce.2). Because reason appearance there still donot hanker and reason hanker the entrepreneurship from Student, hence to overcome it have righteously University of Roman of Santo Thomas Medan form the Unit of Student Co-Operation as training basin and or place learn the entrepreneurship for Student support they become the entrepreneurial to be getting out of unemployment later. 3). For the research of here in after better add the other; dissimilar variable outside this research which can explain the variable of dependen of entrepreneurship interests of Student like opportunity, personality, motivate the entrepreneurship, environmental of family after student become the collegiate and others
\end{abstract}

Keywords: Etrepreneurial knowledge, entrepreneurship interests

\section{PENDAHULUAN}

Jumlah penduduk Indonesia 2020 berada di kisaran 271 juta jiwa (https://news. detik.com.berapa-jumlah-penduduk-indonesia-2020). Pertumbuhan penduduk di Indonesia dari tahun ketahun semakin meningkat. Besarnya jumlah penduduk ini mempunyai arti bahwa pemerintah harus menyiapkan lapangan kerja. Seiring dengan pertambahan jumlah pendudukdan perubahan era pada industrialisasi (4.0) menimbulkan masalah baru juga didalamnya.

Masalah tersebut antara lain menipisnya lapangan pekerjaan, jumlah pencari kerja yang mayoritas merupakan lulusan sarjana meningkat sedangkan lapangan pekerjaan yang ada semakin menipis yang berakibat pada pengangguran. Pengangguran merupakan masalah utama yang sedang dihadapi oleh masyarakat Indonesia saat ini. Terlebih dengan adanya era Masyarakat Ekonomi Asean (MEA) semakin menambah terdesaknya masyarakat Indonesia yang tergeser oleh tenaga asing yang bekerja di Indoonesia, ditambah lagi dengan munculnya bencana Covid-19 yang punya andil menambah jumlah Pemutusan Hubungan Kerja

Pengaruh Pengetahuan Kewirausahaan Terhadap Minat Berwirausaha Mahasiswa (Studi 260 Kasus: Mahasiswa Program Studi Manajemen Fakultas Ekonomi Universitas Katolik Santo Thomas Medan). Oleh : Nawary Saragih 


\section{Volume 20 Nomor 2, September 2020}

PHK. Belum lagi ada wacana moratorium Pegawai Ngeri Sipil 2 tahun ke depan (https://nasional.kompas.com/kemenkeu-moratorium-cpns)

Data statistik terakhir yang diperoleh dari BPS, bulan Februari 2020 menunjukkan:

1. Jumlah angkatan kerja pada Februari 2020 sebanyak 137,91 juta orang, naik 1,73 juta orang dibanding Februari 2019.

2. Dalam setahun terakhir, pengangguran bertambah 60 ribu orang pada Februari 2020.

Ditambah jumlah pengganguran pada pandemik Covid-19

3. Penduduk yang bekerja sebanyak 131,03 juta orang, bertambah 1,67 juta orang dari Februari 2019. Lapangan pekerjaan yang mengalami peningkatan persentase terutama Jasa Pendidikan $(0,24$ persen p oin), Konstruksi ( 0,19 persen poin), dan Jasa Kesehatan ( 0,13 persen poin). Pertambahan tingkat pengangguran pada pandemi covid-19 adalah 3 juta orang (https://www. kompas.tv/ article/ 95702/ imbas-pandemi-pengangguran-bertambah-3-juta-orang. Sementara lapangan pekerjaan yang mengalami penurunan terutama pada Pertanian ( 0,42 persen poin), Perdagangan ( 0,29 persen poin), dan Jasa Lainnya (0,21 persen poin).Selama setahun terakhir (Februari 2019-Februari 2020), persentase pekerja formal meningkat sebesar 0,77 persen poin.

4. Persentase tertinggi pekerja pada Februari 2020 adalah pekerja penuh (jam kerja minimal 35 jam per minggu) sebesar 69,90 persen. Sementara itu, pekerja tidak penuh terbagi menjadi dua, yaitu pekerja paruh waktu ( 23,74 persen) dan pekerja setengah penganggur (6,36 persen). Dalam setahun terakhir, persentase pekerja setengah penganggur turun sebesar 1,01 persen poin, sedangkan persentase pekerja paruh waktu meningkat sebesar 1,07 persen poin(www.bps.go.id)

Berdasarkan informasi di atas artinya bahwa peningkatan yang signifikan pada jumlh pendudukdi Indonesia tidak diikuti dengan peningkatan jumlah lapangan pekerjaan sehingga mengakibatkan pengangguran yang terus bertambah. Maka berdasarkan uraian di atas, penulis tertarik melakukan penelitian dengan judul Pengaruh pengetahuan Kewirausahaan minat berwirausaha mahasiswa pada Program Studi Manajemen Fakultas Ekonomi Universitas Katolik Santo Thomas Medan.

\section{Pengertian Pengetahuan}

\section{TINJAUAN PUSTAKA}

Menurut Bloom dalam (Winkel,2004:283) pengetahuan merupakan suatu memori didalam otak berdasarkan apa yang pernah dipelajari. Sedangkan menurut Djaali (2012:77) pengetahuan adalah kemampuan untuk menghafal, mengingat, memahami atau mengulangi informasi yang pernah diberikan. Artinya pengetahuan terdiri dari pengetahuan langsung yaitu pengetahuan yang diperoleh sebelum seseorang menjadi wirausaha, pengetahuan tidak langsung yang diperoleh dari berbagai pihak yang terjadi ketika seseorang tersebut sebelum menjadi wirausaha atau saat menjadi wirausaha (Widayana, 2005:9).

Berdasarkan beberapa definisi para ahli, dapat disimpulkan bahwa pengetahuan merupakan kemampuan dalam hal mempelajari, mengingat dan menyimpan di dalam otak manusia berdasarkan hal-hal yang pernah diberikan sehingga manusia tersebut tahu tentang suatu informasi.

\section{Pengertian Wirausaha}

Menurut Longenecker (2001:4) wirausaha merupakan pembuat keputusan yang membantu terbentuknya sistem ekonomi perusahaan yang bebas. Wirausaha juga merupakan seseorang yang memulai dan atau mengoperasikan bisnis. Menurut Nitisusastro (2012:26) wirausaha merupakan seseorang yang mengorganisasikan, mengoperasikan dan memperhitungkan risiko untuk sebuah usaha yang mendatangkan laba.

Menurut Suryana \& Bayu(2010:102-117) harus ada tujuan untuk dapat menunjang karakteristik dari seorang wirausaha antara lain:

1. Pekerja Kera

2. Tidak Pernah Menyerah

3. Memiliki Semangat.

4. Memiliki Komitmen.

Menurut Saiman (2009:26) mengemukakan 4 faktor mendorong seseorang untuk berwirausaha, yaitu sebagai berikut:

1. Laba yaitu menentukan berapa laba yang dikehendaki. 


\section{Volume 20 Nomor 2, September 2020}

2. Kebebasan dalam mengatur waktu

3. Impian Personal yaitu lepas dari rutinitas kerja.

4. Kemandirian yaitu manajer terhadap dirinya sendiri.

\section{Pengertian Kewirausahaan}

Kewirausahaan merupakan petualang, pengambil risiko, kontraktor, pengusaha (orang yang mengusahakan sesuatu pekerjaan tertentu, dan pencipta yang menjual hasil hasil ciptaannya (Hendro, 2011: 29). Menurut Hisrich (2001) kewirausahaan diartikan sebuah proses guna menciptakan tambahan kekayaan oleh individu yang telah siap menanggung risiko dalam hal modal dan waktu, selain itu juga menambah nilai darisuatu barang atau jasa. Menurut Saiman (2009:43) kewirausahaan adalah suatu upaya dalam penciptaan kegiatan bisnis atas dasar kemauan dan keinginan dari diri sendiri. Artinya dengan kewirausahaan, maka dapat menciptakan lapangan pekerjaan yangluas, tidak bergantung kepada orang lain dalam mendapatkan pekerjaan dan dapat membantu pemerintah dalam mengurangi pengangguran dengan cara membuka lapangan pekerjaan

\section{Pengertian Pengetahuan Kewirausahaan}

Pengetahuan kewirausahaan melalui mata kuliah kewirausahaan yang diajarkan di perguruan tinggi akan menambah pengetahuan dalam hal teori mengenai kewirausahaan dan praktik yang berupa terjun langsung untuk menjual produk/jasa yang telah diciptakan.

Pengetahuan kewirausahaan merupakan hasil dari proses yang dilakukan oleh indera manusia untuk mengamati, mendengar dan merasakan apa yang wirausahawan lain lakukan dan hasilkan sehing ga manusia tersebut menjadi tahu tentang profesi kewirausahaan. Seseorang yang telah memiliki pengetahuan kewirausahaan akan lebih teliti dalam menganalisis dan mengambil keputusan dalam kelanjutan usahanya (menurut Mustofa dalam penelitian Novianto G.2017)

Harapan dari penelitian ini adalahbagaimana pengetahuan kewirausahaan dapat meningkatkan minat berwirausaha mahasiswa pada Program Studi Manajemen Fakultas Ekonomi Universitas Katolik Santo Thomas Medan karena apabila mahasiswa memiliki minat berwirausaha yang tinggi maka mahasiswa akan lebih tertarik dan mengimplementasikannya dengan membuka peluang usaha baru. Hal ini ikut membantu mendorong perekonomian Indonesia.

\section{Minat Berwirausaha}

Menurut Slameto dalam Winarsih (2014:4) minat adalah suatu rasa lebih suka dan rasa ketertarikan pada suatu hal atau aktivitas, tanpa ada yang menyuruh. Sedangkan menurut Pusat Bahasa Departemen Pendidikan Nasional (2006:656) mendefinisikan minat sebagai kecenderungan hati yang tinggi terhadap sesuatu, gairah dan keinginan. Menurut Hendro (2011:30), berwirausaha adalah kemampuan yang ada pada diri seseorang agar bisa dimanfaatkan secara optimal sehingga bias meningkatkan taraf hidup. berikut:

Faktor yang mendorong minat berwirausaha menurut Bygrave dalam Buchari (2011:11) sebagai

1. Faktor Personal, menyangkut aspek kepribadian:

a. Adanya ketidakpuasan terhadap pekerjaan seseorang

b. Adanya pemutusan hubungan kerja, tidak ada pekerjaan lain

c. Dorongan karena factor usia

d. Keberanian menaggung resiko

e. Komitmen/minat tinggi pada bisnis

2. Faktor Environment, menyangkut hubungan dengan lingkungan fisik:

a. Adanya persaingan dalam dunia kehidupan

b. Adanya sumber-sumber yang bisa dimanfaatkan seperti modal, tabungan, warisan, bangunan, dan lokasi strategis

c. Mengikuti latihan kursus bisnis atau incubator bisnis

d. Kebijaksanaan pemerintah, adanya kemudahan lokasi berusaha, fasilitas Kredit dan bimbingan usaha.

3. Faktor Sosiological, menyangkut hubungan dengan keluarga dan sebagainya:

a. Adanya hubungan-hubungan atau relasi bagi orang lain 


\section{Volume 20 Nomor 2, September 2020}

b. Adanya tim yang dapat diajak kerjasama dalam berusaha

c. Adanya dorongan dari orang tua untuk membuka usaha

d. Adanya bantuan famili dalam berbagai kemudahan

e. Adanya pengalaman bisnis sebelumnya

Menurut Johanes dalam Walgito (1999:35), minat digolongkan menjadi dua, yaitu minat intrinsik dan ekstrinsik.

a. Minat intriksik merupakan minat yang timbul dari dalam diri seseorang tanpa adanya pengaruh dari luar. Minat initimbul karena adanya pengaruh dari sikap, pesepsi, prestasi belajar, bakat, motivasi, jenis kelamin dan harapan bekerja.

b. Minat eksrinsik merupakan minat yang timbul padadiri seseorang karena adanya pengaruh dari luar. Minat ekstrinsik timbul karena adanya pengaruh latar belakang status sosial ekonomi orangtua, minat orangtua, informasi, lingkungan dan lain sebagainya.

Menurut Winkel(2004:212) indikator untuk mengukur minat berwirausaha antara lain:

a. Tidak tergantung pada orang lain

Seorang wirausaha yang telah memulai membuka dan menjalankan usahanya sendiri akan lebih percaya diri untuk bias sukses dimasa depan tanpa perlu bergantung kepada orang lain dalam mendapatkan pekerjaan.

b. Membantu lingkungan sosial

Lingkungan sosial yang ada di sekitar seorang akan terbantu dengan adanya lahan lapangan pekerjaan baru, dengan begitu seorang wirausaha dapat membantu lingkungan sosialnya.

c. Perasaan senang menjadi seorang wirausaha.

Membuat seseorang melakukan aktivitas pekerjaannya secara maksimal dan meningkatkan kegigihan dan semangat untuk berjuang hingga seorang wirausaha tersebut sukses.

\section{Metode Penarikan Sampel}

\section{METODOLOGI PENELITIAN}

1. Populasi seluruh Mahasiswa Program Studi Manajemen Fakultas Ekonomi Universitas Katolik Santo Thomas Medan angkatan tahun 2018/ 2019 sebanyak 159 orang yang sudah menempuh matakuliah kewirausahaan.

2. Teknik yang digunakan untuk pengumpulan data adalah berupa angket/ kuesioner secara online (Google Form)

3. Metode penarikan sampel ditentukan berdasarkan kesalahan (error) maksimum yang diinginkan, dengan rumus (Supranto, 2009:113):

$$
n=\left(\frac{Z_{\alpha / 2}{ }^{2} \times \sigma}{\varepsilon}\right)^{2}=\left(\frac{1,96 \times 0,5}{0,1}\right)^{2}=96,04
$$

Tingkat keyakinan ditetapkan $95 \%\left(\alpha=5 \%\right.$, sehingga $\left.Z^{1} / 2 \alpha=1,96\right)$, kesalahan (error) maksimum $(\varepsilon)=$ 0,1 . standar deviasi $(\sigma)=0,5$; Jumlah sampel yang dibutuhkan $(n)=96,04$ dibulatkan menjadi 96 orang.

\section{Jenis dan sumber data}

Jenis data yang digunakan data skunder dan data primer. Sumber data primer diperoleh dari hasil penyebaran kuesioner kepada Mahasiswa angkatan 2018/2019 secara online pada masa Pandemi Covid-19.

Secara rinci jenis dan sumber data seperti pada tabel berikut:

Tabel 1: Jenis dan sumber data

\begin{tabular}{|l|l|l|}
\hline No. & Data & Sumbert Data \\
\hline 1 & Pelaksanaan kuliah Kewirausaah & Dosen \\
\hline 2 & Data Skunder & KTU Fakultas Ekonomi \\
\hline 3 & Data Primer & Mahasiswa \\
\hline 4 & Profil Responden & Mahasiswa \\
\hline
\end{tabular}

\section{Definisi Operasionalalisasi Variabel Penelitian}




\section{Volume 20 Nomor 2, September 2020}

Dalam penelitian ini, terdapat 2 variabel yaitu: Pengetahuan Kewirausahaan $(\mathrm{X})$ yang menjadi variabel independennya dengan 7 indikator dan variabel Minat Berwirausaha (Y) yang menjadi variabel dependennya dengan 5 indikastor.

\section{Metode Pengumpulan Data}

1. Metode pengumpulan data digunakan kuesioner.

2. Kuesioner dibuat dalam bentuk pertanyaan tertutup dan terbuka

3. Angket dibagikan kepada mahasiswa secara online.

4. Setelah kuesioner diisi, kemudian ditabulasi kembali untuk diolah dengan SPSS versi 22.0 untuk sejumlah 30 orang untuk uji validity dan reabiliy.

5. Dari hasil pengujian jika ada indikator pertanyaan tidak valid dan tidak reliabel maka dikeluarkan dari perhitungan.

6. Selanjutnya dilakukan pengolahan data untuk analisis lebih lanjut maupun untuk menarik kesimpulan dan saran.

\section{Metode Analisis Data}

a. Uji Validitasi

Uji validitas berguna untuk menguji ketepatan hasil kuesioner. Jumlah sampel digunakan 30 orang". Dianggap memenuhi syarat kalau $r>0,3$. Jika korelasi antara butir dengan skor total $<0,3$, maka butir dalam instrumen tersebut dinyatakan tidak valid. Untuk menghitung koefisien korelasi digunakan "corrected Item-Total Correlation"

\section{b. Uji Reliabilitas}

Uji reliabilitas dapat dilakukan dengan Cronbach's Alpha if Item Deleted. jika reliabilitas hitung: Jika $\alpha>0,50$ artinya instrumen reliabel, jika $\alpha<0,50$ artinya instrumen tidak reliabel.

\section{c. Analisis Data}

Analisis data digunakan regresi linear sederhana untuk mengetahui pengaruh Pengetahuan Kewirausahaan terhadap Minat Berwirausaha Mahasiswa Program studi Manajemen Fakultas Ekonomi Universitas Katolik Santo Thomas Medan.

Model analsisinya: $\mathrm{Y}_{\mathrm{i}}=\mathrm{b}_{0}+\mathrm{b}_{1} \mathrm{x}_{1}+\varepsilon$

Langkah pengujian hipotesis dengan prosedur:

1. $\mathrm{H}_{0}:$ bi $=0$, artinya Pengetahuan Kewirausahaan tidak mempunyai pengaruh yang positif dan signifikan terhadap Minat Berwirausaha Mahasiswa Program studi Manajemen Fakultas Ekonomi Universitas Katolik Santo Thomas Medan

$\mathrm{H}_{1}$ : bi $\neq 0$, artinya Pengetahuan Kewirausahaan mempunyai pengaruh yang positif dan signifikan terhadap Minat Berwirausaha Mahasiswa Program studi Manajemen Fakultas Ekonomi Universitas Katolik Santo Thomas Medan

2. Sampel : 96 responden dengan Level of significance (1- $\alpha): 95 \%$

3. Uji statistik Z: $Z=\frac{b i}{S_{e b}}$

\section{Keterangan:}

$\mathrm{z}=\mathrm{z}$-hitung. $\mathrm{bi}=$ Koefisien regresi. $\mathrm{S}_{\mathrm{eb}}=$ Standar error koefisien regresi Nilai tabel $: \mathrm{z}(\alpha / 2) . \mathrm{H}_{0}$ diterima jika $-z(\alpha / 2) \leq z_{\text {hitung }} \leq z(\alpha / 2)$

$$
\mathrm{H}_{1} \text { diterima jika } \mathrm{Z} \text {-hitung }<-z(\alpha / 2) \text { atau } z_{\text {hitung }}>z(\alpha / 2)
$$

4. Kriteria pengujian: $\mathrm{H}_{0}$ diterima apabila $\mathrm{Z}$ - hitung $<\mathrm{Z}$-tabel. $\mathrm{H}_{1}$ diterima apabila Z- hitung > Z- tabel

5. Koefisien Determinasi (R2)

Koefisien determinasi untuk mengukur kemampuan variabel independent dalam menjelaskan variasi variabel dependent amat terbatas.

\section{HASIL PENELITIAN DAN PEMBAHASAN}

\section{Deskripsi Data Penelitian}


Volume 20 Nomor 2, September 2020

Karakteristik pekerjaan orangtua disajikan pada diagram batang berikut:

Tabel 2: Pekerjaan orang tua

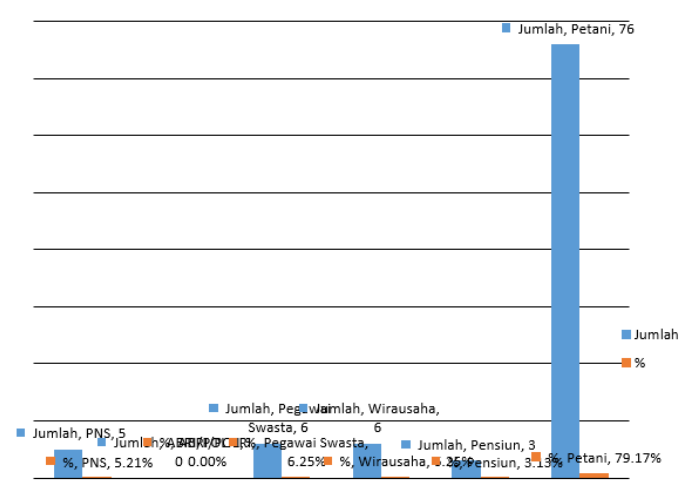

Sumber:Data Primer yang diinventarisasi 2020

Karakteristik asal responden dari keluarga Wirausaha:

Tabel 3: Berasal dari keluarga Wirausaha

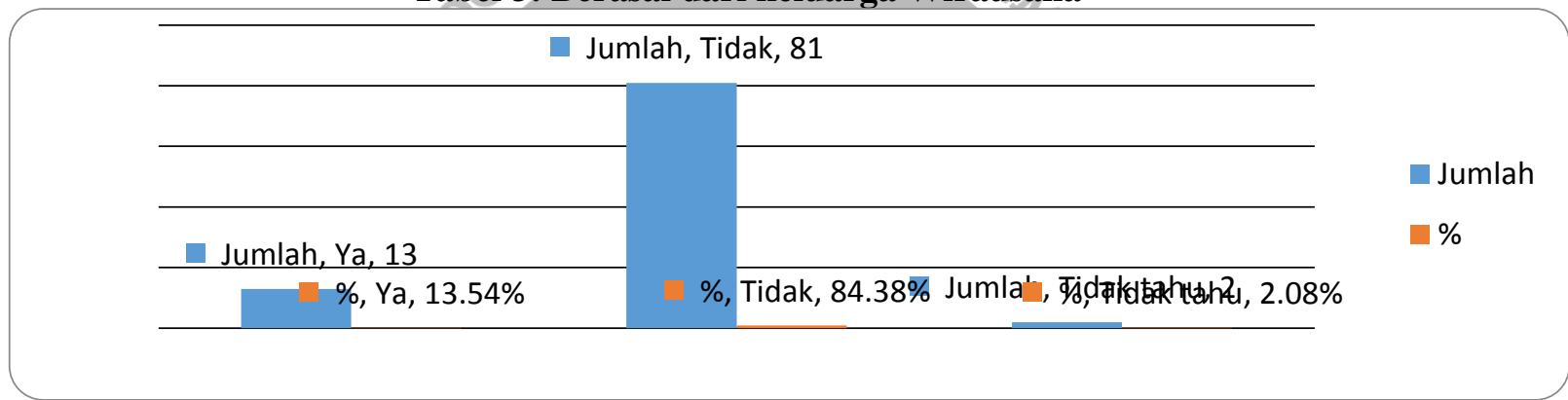

Sumber:Data Primer yang diinventarisasi 2020

Karakteristik minat untuk Berwirausaha:

Tabel 4: Berminat untuk Berwirausaha

\begin{tabular}{ccc}
\hline & Jumlah, Tidak tahu, \\
\hline & Jumlah, Tidak, 40 & \\
\hline Jumlah, Ya, 20 & & $\%$, Tidak tahu, \\
\hline & & $37.50 \%$ \\
\hline
\end{tabular}

Sumber:Data Primer yang diinventarisasi 2020

Karakteristik telah memulai dan menjalankan usaha:

Tabel 5: Telah memulai dan menjalankan usaha

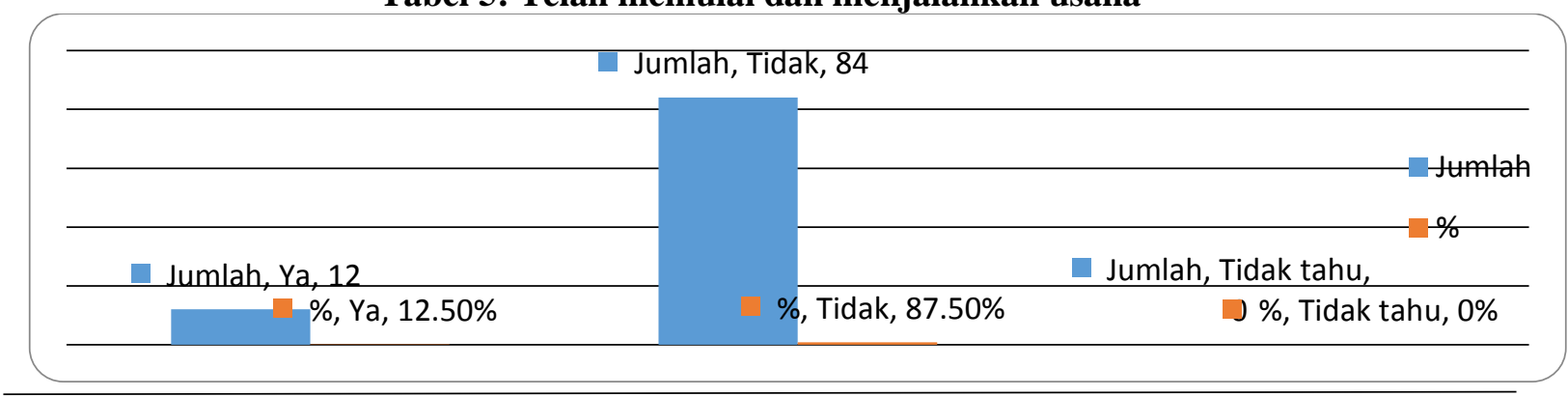

Pengaruh Pengetahuan Kewirausahaan Terhadap Minat Berwirausaha Mahasiswa (Studi 
Volume 20 Nomor 2, September 2020

Sumber:Data Primer yang diinventarisasi 2020

Tabel 6: Alasan berminat untuk Berwirausaha

\begin{tabular}{|c|c|}
\hline No. & Alasan berminat \\
\hline 1 & Ingin memiliki usaha sendiri (Mandiri) \\
\hline 2 & Menciptakan lapangan pekerjaan \\
\hline 3 & Untuk menambah penghasilan dan pengalaman \\
\hline 4 & Membahagiakan keluarga/orang tua \\
\hline 5 & supaya mampu menciptakan inovasi baru \\
\hline 6 & Saya ingin berpenghasilan dari usaha yang saya bangun \\
\hline 7 & Mewujudkan kreatifitas saya \\
\hline
\end{tabular}

Sumber:Data Primer yang diinventarisasi 2020

Tabel 7: Alasan tidak berminat Berwirausaha

\begin{tabular}{|r|l|}
\hline \multicolumn{1}{|c|}{ No. } & \multicolumn{1}{|c|}{ Alasan tidak berminat } \\
\hline 1 & Sampai sekarang saya belum terfikir untuk melakukan wirausaha \\
\hline 2 & Karena besarnya resiko kegagalan di masa yang akan datang. \\
\hline 3 & Karena kondisi keuangan/ Tidak adanya modal \\
\hline 4 & Karena kurang kreatif \\
\hline 5 & Saya tidak memiliki persiapan mental untuk menghadapi kegagalan \\
\hline 6 & Tidak adanya mentor yang mengarahkan \\
\hline 7 & Karena ingin menjadi PNS \\
\hline 8 & Orang tua saya tidak setuju bila saya menjadi wirausaha \\
\hline 9 & Karna kurang dukungan dari keluarga \\
\hline
\end{tabular}

Sumber: Data Primer yang diinventarisasi 2020

Dari deskripsi data penelitian bahwa karakteristik responden dimana pekerjaan orangtua dominan sebagai Petani sebesar 79,17\%, tidak berasal dari keluarga Wirausahawan sebesar 84,38\%. Berminat untuk Berwirausaha sebesar 20,83\%. Responden yang telah memulai dan menjalankan usaha sebesar $12,5 \%$. Sedangkan aneka ragam alasan berminat dan alasan tidak berminat responden untuk Berwirausaha seperti tertera pada tabel 6 dan tabel 7.

\section{Hasil Uji Validitas dan Reliabilitas}

Tabel 8: Hasil Uji Validitas dan Reliabilitas Instrumen Item-Total Statistics

\begin{tabular}{|r|r|r|r|r|}
\hline Variabel & $\begin{array}{c}\text { Scale Mean if } \\
\text { Item Deleted }\end{array}$ & $\begin{array}{c}\text { Scale Variance if } \\
\text { Item Deleted }\end{array}$ & $\begin{array}{c}\text { Corrected Item- } \\
\text { Total Correlation }\end{array}$ & $\begin{array}{c}\text { Cronbach's Alpha } \\
\text { if Item Deleted }\end{array}$ \\
\hline v1 & 50.7333 & 14.754 & .419 & .860 \\
\hline $\mathrm{v} 2$ & 50.6667 & 15.195 & .355 & .863 \\
\hline $\mathrm{v} 3$ & 50.8333 & 14.902 & .424 & .859 \\
\hline $\mathrm{v} 4$ & 51.0000 & 12.966 & .676 & .842 \\
\hline $\mathrm{v} 5$ & 50.3333 & 14.920 & .594 & .848 \\
\hline $\mathrm{v} 6$ & 50.7667 & 13.357 & .680 & .840 \\
\hline $\mathrm{v} 7$ & 50.5000 & 15.155 & .471 & .854 \\
\hline $\mathrm{V} 8$ & 52.1000 & 15.197 & .683 & .846 \\
\hline $\mathrm{V} 9$ & 50.0667 & 16.202 & .707 & .854 \\
\hline $\mathrm{v} 10$ & 51.0667 & 16.202 & .707 & .854 \\
\hline $\mathrm{v} 11$ & 52.0667 & 16.202 & .707 & .854 \\
\hline $\mathrm{v} 12$ & 50.1333 & 14.257 & .657 & .843 \\
\hline $\mathrm{v} 13$ & 50.1333 & 14.257 & .657 & .843 \\
\hline
\end{tabular}

Sumber: Lampiran 3 


\section{Volume 20 Nomor 2, September 2020}

Dari Tabel 8, ditunjukkan bahwa setiap indikator penelitian yang terdiri dari 13 indikator pengukuran pengetahuan kewirausahaan dan Minat Berwirausaha seluruhnya sudah valid, sehingga dapat digunakan untuk mengukur variabel yang diteliti, karena r-hitung > r-kritis $(0,30)$. Berdasarkan tabel 7, menunjukkan bahwa seluruh indikator pengukuran pengetahuan kewirausahaan dan Minat Berwirausaha sudah reliabel, dan dapat digunakan untuk mengukur variabel yang diteliti, karena nilai alpha $>0,50$.

\section{Pembuktian Hipotesis}

a. Hasil analisis diperoleh persamaan regresi linear sederhana adalah $Y=1,966+0,490$ (x). Artinya, pengetahuan kewirausahaan berpengaruh positif dan signifikan terhadap Minat Berwirausaha Mahasiswa. Hal ini dapat dilihat dari nilai koefisien regresinya yang bertanda positif.

b. Nilai koefisien korelasi sebesar 0,480. Artinya, pengetahuan kewirausahaan mempunyai hubungan positif terhadap Minat Berwirausaha Mahasiswa.

c. Nilai koefisien determinan sebesar 0,230 artinya Minat Mahasiswa berwirausaha dapat dijelaskan oleh pengetahuan Kewirausahaan $23 \%$ sedangkan $77 \%$ lagi dijelaskan oleh faktor lain yang tidak dibahas dalam penelitian ini.

d. Hasil pengujian diperoleh $=\mathrm{Z}$-hitung=5,306 $>$ Z-tabel=1,96 dengan tingkat signifikansi $0,000<$ 0,05 maka $\mathrm{H}_{0}$ ditolak dan $\mathrm{H}_{1}$ diterima. Artinya, pengetahuan kewirausahaan mempunyai pengaruh positif dan signifikan terhadap Minat Berwirausaha Mahasiswa Program Studi Manajemen Fakultas Ekonomi Universitas Katolik Santo Thumas Medan

\section{PEMBAHASAN}

Penelitian ini bertujuan untuk menguji pengaruh Pengetahuan Kewirausahaan terhadap Minat Berwirausaha mahasiswa. Berdasarkan hasil analisis, maka pembahasaan dari hasil penelitian ini mendukung hipotesis yang menyatakan bahwa terdapat pengaruh positif Pengetahuan Kewirausahaan terhadap Minat Berwirausaha Mah a si sw a dengannilai koefisien regresi sebesar 0,490.

Hal tersebut menunjukkan bahwa apabila nilai Pengetahuan Kewirausahaan (X) mengalami peningkatan sebesar1 satuan, maka nilai Minat Berwirausaha Mahasiswa akan meningkat sebesar 0,490 satuan.Variabel Pengetahuan Kewirausahaan memiliki Z-hitung sebesar 5,306 dimana lebih besar dari pada nilai Z-tabel yaitu sebesar 1,65 dengan nilai signifikansi sebesar 0,000 lebih kecil dari pada 0,05.

Hasil penelitian ini konsisten dengan hasil penelitian yang dilakukan oleh Mustofa dalam Novianto G.(2017) yang menyatakan bahwa Pengetahuan Kewirausahaan berpengaruh positif terhadap Minat Berwirausaha. Pengetahuan kewirausahaan merupakan hasil dariproses yang dilakukan oleh indera manusia untuk menga mati, mendengar dan merasakan apa yang wirausahawan lain lakukan dan hasilkan sehing ga manusia tersebut menjadi tahu tentang profesi kewirausahaan. Seseorang yang telah memiliki pengetahuan kewirausahaan akan lebih teliti dalam menganalisis dan mengambil keputusan dalam kelanjutan usahanya.

Pengetahuan kewirausahaan yang mahasiswa peroleh di perguruan tinggi melalui mata kuliah kewirausahaan dapat membantu mahasiswa dalam menganalisis mengenai aspek lokasi, keuangan, dan lain sebagainya yang terkait dengan kewirausahaan. Pengetahuan kewirausahaan akan menanamkan nilai-nilai kewirausahaan yang nantinya akan membentuk pola pikir dan sikap mental berwirausaha sehingga akan meningkatk an minat berwirausaha para mahasiswa.

Analisis tehadap Pengaruh Pengetahuan Kewirausahaan Terhadap Minat Berwirausaha Mahasiswa Program studi Manajemen Fakultas Ekonomi Universitas Katolik Santo Thomas Medan seperti pada tabel berikut:

Tabel 9: Jumlah bobot jawaban Pengetahuan Kewirausahaan

\begin{tabular}{|c|c|c|c|c|c|}
\hline No Pertanyaan & SS & S & CS & TS & STS \\
\hline 1 & 35 & 53 & 8 & 0 & 0 \\
\hline 2 & 36 & 55 & 5 & 0 & 0 \\
\hline 3 & 30 & 57 & 9 & 0 & 0 \\
\hline 4 & 27 & 49 & 17 & 3 & 0 \\
\hline 5 & 66 & 28 & 2 & 0 & 0 \\
\hline
\end{tabular}

Pengaruh Pengetahuan Kewirausahaan Terhadap Minat Berwirausaha Mahasiswa (Studi 
Volume 20 Nomor 2, September 2020

\begin{tabular}{|c|c|c|c|c|c|}
6 & 34 & 49 & 13 & 0 & 0 \\
\hline 7 & 42 & 52 & 2 & 0 & 0 \\
\hline Jumlah bobot & 270 & 343 & 56 & 3 & 0 \\
\hline$\% \mathrm{Jb}$ & 40.18 & 51.04 & 8.33 & 0.45 & 0.00 \\
\hline
\end{tabular}

Dari 96 responden yang menyatakan jumlah bobot jawaban dari ketujuh pertanyaan pengetahuan Kewirausahaan setuju sebesar 40,18. Setuju sebesar 51,04 \%. Cukup setuju sebesar 8,33 $\%$. Tidak setuju sebesar $0,45 \%$. Sangat tidak setuju sebesar $0,00 \%$. Dari persentase tersebut, dapat dikatakan bahwa Mahasiswa dominan setuju sebesar 51,04 \% terhadap mata kuliah pengetahuan Kewirausahaa diadakan pada kurikulum.

Dari jumlah bobot jawaban Pengetahuan Kewirausahaan untuk kemudahan pemahaman disajikan dalam bentuk diagram garis berikut:

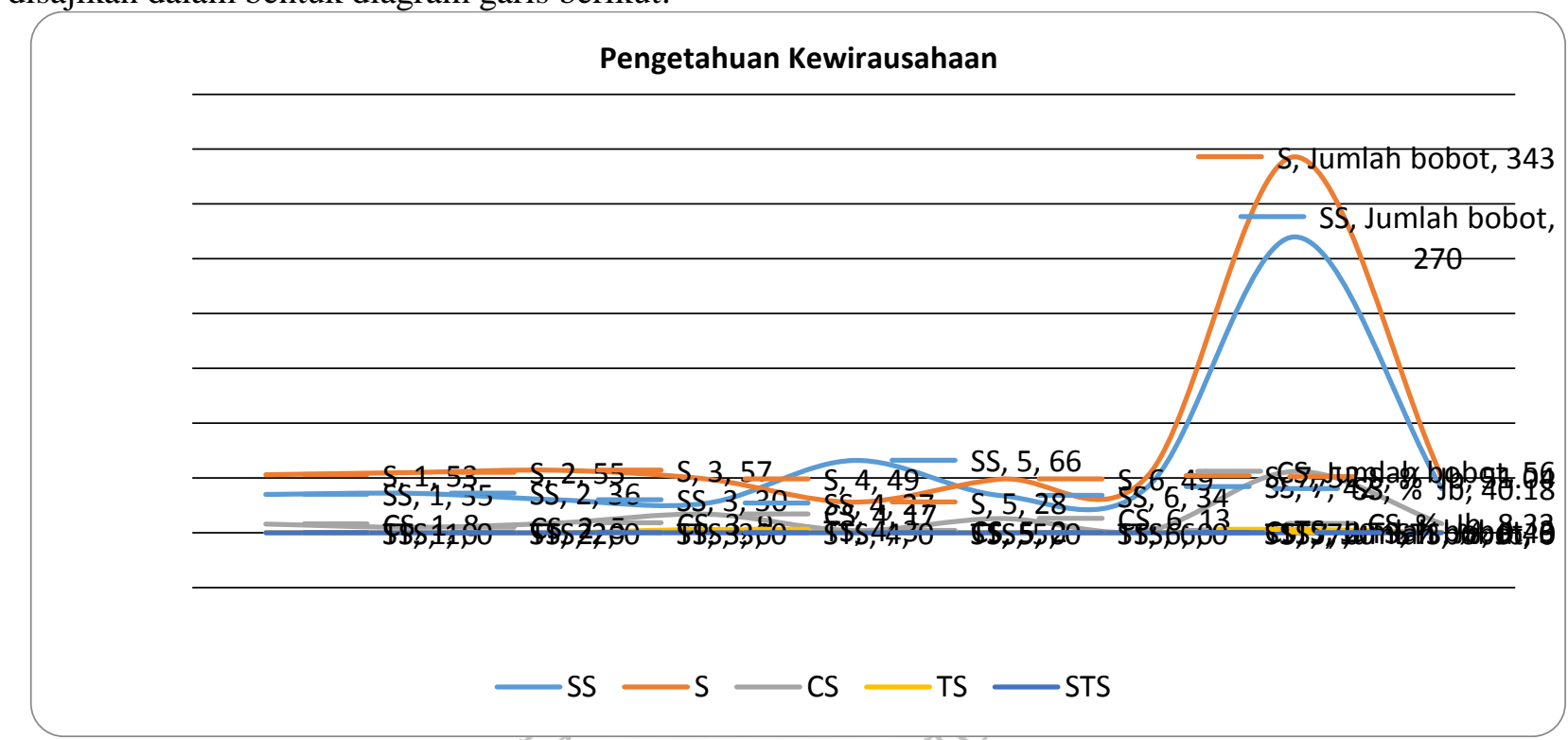

Tabel 10: Jumlah bobot jawabăn Minat Berwirausaha

\begin{tabular}{|c|c|c|c|c|c|}
\hline No Pertanyaan & SS & S & CS & TS & STS \\
\hline 1 & 30 & 40 & 16 & 9 & 1 \\
\hline 2 & 33 & 56 & 7 & 0 & 0 \\
\hline 3 & 16 & 38 & 29 & 12 & 1 \\
\hline 4 & 29 & 43 & 16 & 8 & 0 \\
\hline 5 & 28 & 35 & 20 & 11 & 2 \\
\hline Jumlah bobot & 136 & 212 & 88 & 40 & 4 \\
\hline \% JB & 28.33 & 44.17 & 18.33 & 8.33 & 0.83 \\
\hline
\end{tabular}

Dari 96 responden yang menyatakan jumlah bobot jawabandari lima pertanyaan minat berwirausaha sangat setuju sebesar $28,33 \%$. Setuju sebesar 44,17\%. Cukup setuju sebesar 18,33\%. Tidak setuju sebesar 8,33\%. Sangat tidak setuju sebesar 0,83\%. Dari persentase tersebut, dapat dikatakan bahwa Mahasiswa dominan setujusebesar 44,17 \% bahwa mata kuliah pengetahuan Kewirausahaa dapat mendukung motivasi berminat berwirausaha.

Dari jumlah bobot jawaban Minat Berwirausaha untuk kemudahan pemahaman disajikan dalam bentuk diagram garis berikut: 


\section{Volume 20 Nomor 2, September 2020}

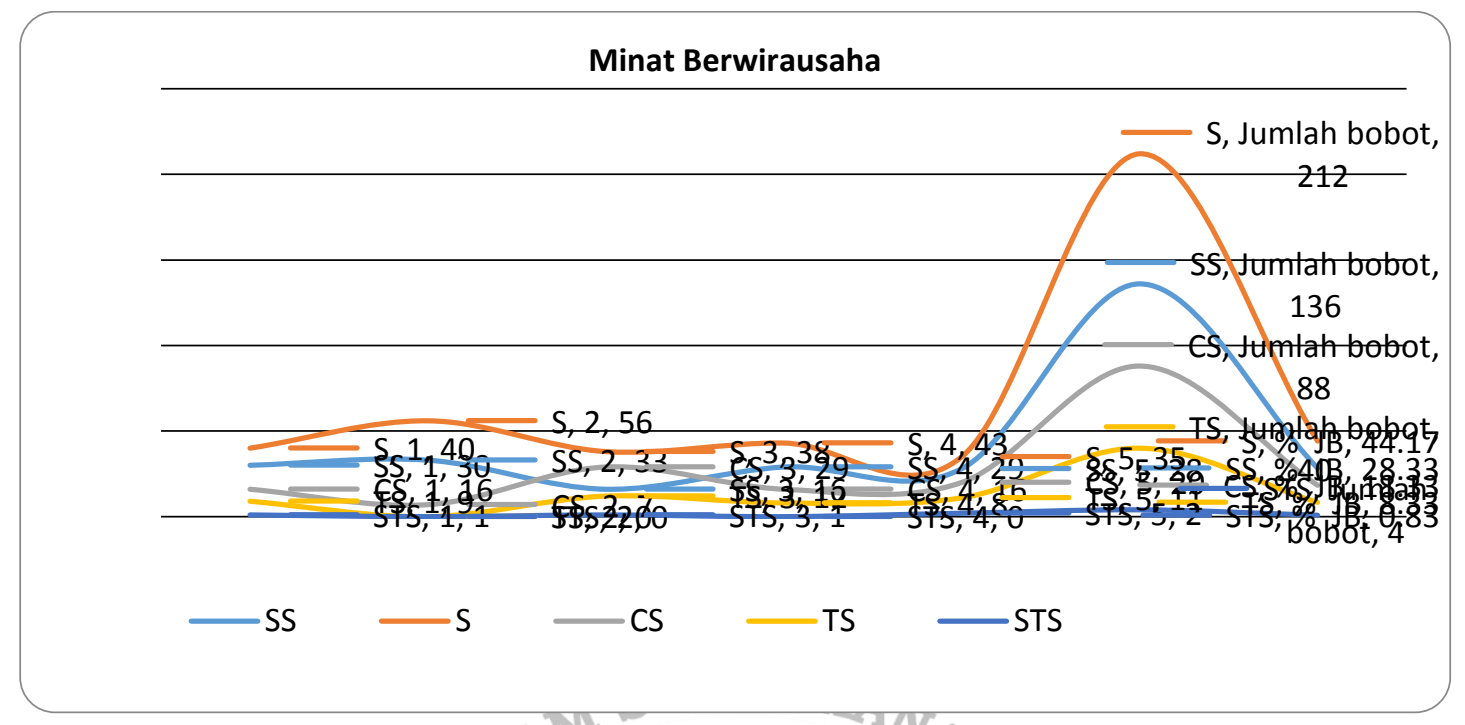

Berdasarkan uraian jumlah bobot jawaban di atas, bahwa pengetahuan kewirausahaan bagi Mahasiswa dominan setujusebesar 51,04 \% terhadap mata kuliah pengetahuan Kewirausahaa. Sedangkan sebesar 44,17 \% bahwa mata kuliah pengetahuan Kewirausahaa dapat mendukung motivasi Mahasiswa untuk berminat berwirausaha.

Pilihan responden dominan setuju ini muncul karena ada harapan mereka bahwa dengan belajar Kewirausahaan tentu dapat memotivasi mereka berminat berwirausaha karena:

1. Ingin memiliki usaha sendiri (Mandiri)

2. Menciptakan lapangan pekerjaan

3. Untuk menambah penghasilan dan pengalaman

4. Membahagiakan keluarga/orang tua

5. Supaya mampu menciptakan inovasi baru

6. Berpenghasilan dari usaha yang dibangun

7. Mewujudkan kreatifitas

Namun, jika dilihat dari persamaan regresi linear sederhana adalah $\mathrm{Y}=1,966+4,490$ (x). Hasil penelitian diperoleh Koefisien determinasi $\left(\mathbf{R}^{2}\right)$ sebesar 0,230 artinya bahwa pengetahuan Kewirausahaan hanya mampu menjelaskan Minat Berwirausaha Mahasiswa sebesar 23,0 dan 77,0 \% lagi dipengaruhi oleh faktor lain yang tidak dijelaskan pada penelitian ini.

Persamaan regresi $\mathrm{Y}=1.966+0,490+\mathrm{e}$. Di mana tingkat signifikan 0.000 lebih kecil dari standar signifikan yakni 5\% (0,05), dimana z-hitung sebesar $5.306>$ z-tabel sebesar 1,65 maka Ho ditolak artinya pengetahuan Kewirausahaan memiliki pengaruh yang positif terhadap Minat Berwirausaha Mahasiswa

Dilihat dari hasil penelitian dimana Koefisien determinasi $\left(\mathrm{R}^{2}\right)$ bahwa masih ada 77,0\% lagi belum dijelaskan yang dapat menumbuhkan minat mahasiswa untuk berwirausaha. Namun dalam tuntutan sekarang ini bahwa pengetahuan kewirausahaan merupakan kemampuan seseorang yang diperoleh melalui teori-teori dibangku pendidikan yang berkaitan dengan kewirausahaan tidak cukup, maka solusi perlu bertukar pengalaman dari wirausahawan. Selain itu, pengetahuan kewirausahaan dapat diperoleh melalui berbagai media baik cetak maupun elektronik (youtube). Sebab semakin sering seseorang menerima informasi mengenai pengetahuan kewirausahaan, akan berdampak positif dalam meningkatkan minat berwirausaha.

Melalui pengetahuan kewirausahaan, seseorang dapat menciptakan berbagai ide dan inovasi dibidang kewirausahaan sehingga dapat menciptakan peluang untuk berwirausaha. Oleh sebab itu, diharapkan dengan semakin mudahnya mengakses berbagai pengetahuan mengenai kewirausahaan, diharapkan dapat meningkatkan minat berwirausaha pada mahasiswa. Dengan demikian, semakin banyak pengetahuan kewirausahaan yang diperoleh maka akan semakin menumbuhkan minat berwirausaha padamahasiswa. 


\section{Kesimpulan}

\section{KESIMPULAN DAN SARAN}

Terdapat pengaruh positif Pengetahuan Kewirausahaan terhadap Minat Berwirausaha pada Mahasiswa. Hal tersebut dapat dibuktikan dengan nilai z-hitung sebesar 5,306 > nilai z-tabel yaitu sebesar 1,65 dengan nilai signifikansi sebesar $0,000<0,05$ serta memiliki nilai koefisien regresi sebesar 0,230. Semakin banyak Pengetahuan Kewirausahaan yang diperoleh maka akan semakin menumbuhkan Minat Berwirausaha Mahasiswa.

Terdapat pengaruh positif Pengetahuan Kewirausahaan. Hal tersebut dibuktikan dari hasil regresi linear sederhana yang menghasilkan nilai F-hitung sebesar 28,154>F-tabel sebesar 1,96 dengan nilai signifikansi $0,000<$ dari 0,05 . Variabel Pengetahuan Kewirausahaan memberikan nilai koefisien sebesar 0,230.

\section{Saran}

Karena koefisien determinasi $\left(\mathrm{R}^{2}\right)$ sebesar 0,230 artinya masih rendah pengaruh pengetahuan Kewirausahaan mampu menjelaskan Minat Berwirausaha Mahasiswa, maka untuk mendukung maupun untuk menumbuhkan minat berwirausaha Mahasiswa diperlukan peningkatan materi kuliah Kewirausahaan lebih aplikatif dengan dukungan sinergi dari mata kuliah lain seperti Pengatar Bisnis. Marketing, e-commerce.

Dengan munculnya alasan tidak berminat dan alasan berminat berwirausaha dari Mahasiswa, maka untuk mengatasinya sudah selayaknya Universitas Katolik Santo Thomas Medan menendirikan unit sebagai wadah pelatihan (magang) ataupun tempat belajar berwirausaha bagi Mahasiswa untuk mendukung minat mereka menjadi Wirausaha agar lepas dari pengangguran kelak (misalnya Koperasi Mahasiswa)

Untuk penelitian selanjutnya sebaiknya menambah variabel lain diluar penelitian ini yang dapat menjelaskan variabel dependen

\section{DAFTAR PUSTAKA}

Alma, B. (2011). Kewirausahaan Untuk Mahasiswa dan Umum. Bandung: Alfabeta.

Djaali,H.(2007).Psikologi Pendidikan. Jakarta: BumiAksara.

Hendro.(2011). Dasar-dasar Kewirausahaan.Jakarta: PenerbitErlangga.

Hisrich R.D., Peters M.P.\& Shepherd D.A.(2008).Entrepreneurship. Jakarta: Salemba Empat.

Longenecker J.G.,MooreC.W.\&PettyJ.W.(2001).Kewirausahaan Manajemen Usaha Kecil. Jakarta:

SalembaEmpat.

Nitisusastro, M. (2012). Kewirausahaan dan Manajemen Usaha Kecil.Bandung: CV.Alfabeta.

Noviantoro, G.(2017). Pengaruh Pengetahuan Kewirausahaan, Motivasi Berwirausaha

dan Lingkungan Keluarga Terhadap Minat Berwirausaha, Universitas Negeri

Yogyakarta

Pusat Bahasa Departemen Pendidikan Nasional. (2006). Kamus Besar Bahasa Indonesia. Jakarta: Balai Pustaka.

Saiman, L. (2009). Kewirausahaan, Teori, Praktik, dan Kasus-kasus. Jakarta: SalembaEmpat.

Slameto. (2010). Belajar dan Faktor-Faktor yang Mempengaruhinya. Jakarta: RinekaCipta.

Sugiyono.(2011). Metode Penelitian Kuantitatif Kualitatif R\&D. Edisi 13.

Bandung:Alfabeta.

Suryana,Y.(2013).Kewirausahaan.Jakarta:Kencana.

Suryana, Y. \&Bayu, K. (2010). Kewirausahaan Pendekatan Karakteristik

Wirausahawan Sukses.Jakarta:Kencana.

Walgito, B.(1999).Psikologi Sosial Suatu Pengantar. Yogyakarta: ANDI.

Winkel,W.S.(2004). Psikologi Pengajaran.Jakarta:Grasindo. 